\title{
The Management of Innovation Networks: Possibilities of Collaboration in Light of Game Theory
}

\author{
Samuel Façanha Câmara ${ }^{1}$, Brenno Buarque de Lima ${ }^{2}$, Teresa Lenice Nogueira da Gama Mota ${ }^{3}$, Alanna Lima e Silva ${ }^{4}$, \\ Pablo Padilha ${ }^{5}$ \\ ${ }^{1}$ Assistant Professor at the State University of Ceará, Brazil \\ ${ }^{2}$ Master's student in Business Administration at the State University of Ceará, Brazil \\ ${ }^{3}$ Post Doctoral at the State University of Ceará, Professor at College Luciano Feijão, Brazil \\ ${ }^{4}$ Degree in Management at College Luciano Feijão, Brazil \\ ${ }^{5}$ Master in Business Administration from Fundação Instituto de Administração FIA / USP, Executive Innovation \\ Manager of the Federation Industries of the State of Ceará, Brazil \\ Correspondence: Brenno Buarque de Lima, Master's student in Business Administration at the State University of Ceará, \\ Brazil.
}

Received: February 8, 2018

Accepted: March 21, 2018

Online Published: April 2, 2018

doi:10.11114/bms.v4i2.3003

URL: https://doi.org/10.11114/bms.v4i2.3003

\begin{abstract}
The purpose of the present article is to demonstrate how understanding the rationality of the agents of innovation networks can be useful to strategically formulate their management, in light of the prisoner's dilemma. This research was undertaken using a theoretical test that addresses the topics of network governance and management, collaboration and game theory. The results may contribute to the literature on network governance and management, more specifically to the field of innovation networks, by proposing scenarios upon which network managers can build in order to develop governance strategies. Moreover, management mechanisms are also proposed, adjusted to the innovation networks, in order to encourage collaboration among the participants of these innovative environments.
\end{abstract}

Keywords: innovation networks, network management, collaboration, game theory

\section{Introduction}

Inter-organizational cooperation networks have been researched in the field of Management, especially in the area of innovation management (Tsai, 2001; Capaldo, 2007; Zeng, Xie \& Tam, 2010). Studies in this area have been extensive, addressing governance structure models and collective relationship strategies. Regarding governance aspects, there are studies addressing the characteristics of management that influence the dynamics of networks and their governance structures regarding the rules and sanctions that set out the standards to regulate the relationships between the participants in an inter-organizational network (Provan \& Kenis, 2008; Camargo, Verschoore \& Padilha, 2013; Verschoore, Balestrin $\&$ Perucia, 2014).

The literature about collective relationship strategies and social network mechanisms is vast, dealing with trust, collaboration and relational views (Gulati, 1995; Jones, Hesterly \& Borgatti, 1997; Cullen, Johnson \& Sakano, 2000; Dyer \& Nobeoka, 2000; Provan, Fish \& Sydow, 2007; Bortolaso, Verschoore \& Do Vale Jr, 2012; Balestrin, Verschoore $\&$ Perucia, 2014). Relational views of the relationships among the participants in a network are very important for the management model of an inter-organizational network, because those relationships directly influence people's decision to cooperate, or not, making them a key criterion for generating innovation in organizations (Balestrin \& Verschoore, 2010).

For that matter, few studies address how governance influences relational views and how network management models and their mechanisms might influence collaborative behavior. Although a number of studies have addressed the topic of relationships and collaboration (Gulati, 1995, 1998; Jones et al., 1997; Alves, Balsan, De Moura \& Pereira, 2011; Balestrin \& Verschoore, 2014), few explore the present research question: how can a management model and its governance influence the network participants' decision to collaborate?

Based on this question, a test was designed to understand how the rationality of the agents involved in innovation 
networks, considering the prisoner's dilemma, can be useful to strategically formulate the management of such environments. Considering the dilemma of cooperation that arises from game theory, the study attempts to demonstrate that collaboration can be encouraged in different contexts, taking into consideration the relationships between the players and governance and the mechanisms of management.

This study comprises six sections, including this introduction. The following section deals with the review of literature on network governance and management, followed by a section focusing on game theory, collaborative behavior and innovation networks; the third section proposes and discusses an analytical framework. The fourths section addresses the research methodology. The fifth section displays the results and discusses the prisoner's dilemma and collaboration in inter-organizational networks, leading to governance strategies and innovation network management mechanisms and the conclusions.

\section{Theoretical Framework}

\subsection{Network Governance and Management}

Several studies have explored the topic of network governance and management from the point of view of governance structure (Provan \& Kenis, 2008; Balestrin et al., 2014). According to Brand, Rigoni and Verschoore (2014), governance consists of setting control mechanisms, incentives, rules and penalties, and coordinating the actions of network players, which the authors define as "collective structuring". These elements of governance are the mechanisms used by managers and network players to ensure better control over the formal and informal aspects of the network (Brand, Rigoni \& Verschoore, 2014).

Concerning network management, Roth, Wegner, Junior \& Padula (2012) state that management is responsible for positively influencing the members' competitiveness and for reaching the goals proposed by the organizations. The authors also list some of the roles of inter-organizational network management: member selection; planning and communication; assessment; integration; providing services to members; coordination; incentives and controls. In the aforementioned article, Roth et al. (2012) illustrate the relationship between the concepts of governance and network management, as shown in Figure 1:

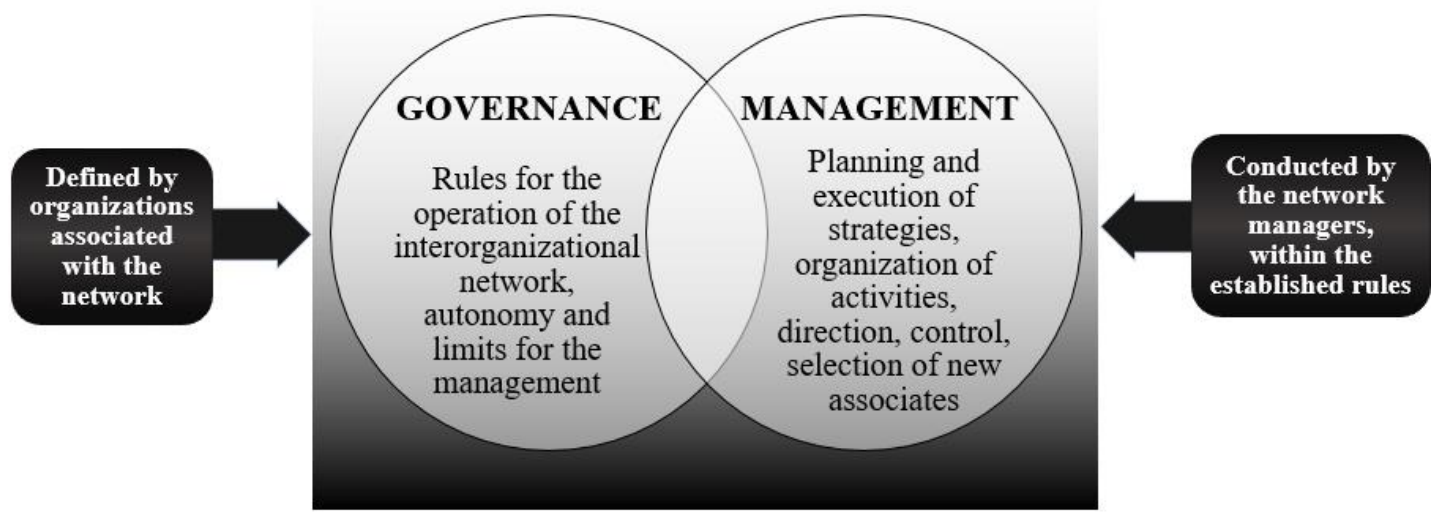

Figure 1. Governance system and inter-organizational network management

Source: Translated and adapted from Roth et al. (2012)

Provan and Kenis (2008) also contributed to the discussion by proposing three forms of network administration: shared governance among the members of the network, when the organizational leader, who is a member acting as leader, coordinates the network activities and decisions; the Network Administrative Organization (NAO) model, in which the network is governed by an administrative entity separate from its members, which can be set up by its members or appear naturally when the network is formed; and Participant-Governed Network (PGN), in which the network is governed formally or informally by its participants. Regarding network management practices, Verschoore et al. (2014) also add some valuable guidelines for a network management assessment model: strategy, structure, coordination, processes and relationships. These are guidelines that network managers can use to identify gaps and failures in management and take the necessary actions. All these forms of network governance and management guidelines emphasize control structure and governance coordination.

However, a cooperative network management model needs to address relational views, such as building up trust (Zaheer, McEvily \& Perrone, 1998; Cullen et al., 2000; Boaventura, Carnaúba, Todeva, Azevedo \& Armando, 2016), sharing information (Tsai, 2001), interdependent relations, lasting relationships (Gulati, 1998), alliances and solidarity behavior 
(Gulati, 1995). Networks consist of and are sustained mainly by relationships between their participants (Capaldo, 2007; Balestrin \& Verschoore, 2010). According to Brand et al. (2014) the agreements created by the relationships between the players of a cooperative network are more important than the established formal agreements. The authors also state that these management aspects, regarding relationships, are referred to as relational governance.

Therefore, the aspects addressing trust, cooperation and reputation between the participants of a network are very important, since they are directly related to the performance (Zaheer et al., 1998; Dyer \& Nobeoka, 2000; Balestrin et al., 2014; Boaventura et al., 2016). The governance of a network needs to have clear goals, structured using the so-called formal governance mechanisms and management practices. But it is important that both network managers and participants are aware of the social mechanisms in place, since they are responsible for ensuring the maintenance and the sustainability of the network (Jones et al., 1997; Cullen et al., 2000; Brand et al., 2014).

Thus, the challenges to network management are: first, to allow members to participate, so it is possible for them to envision the benefits of belonging to the network, consequently becoming motivated to collaborate. Secondly, it is necessary to create and develop the formal governance mechanisms and management practices. However, productive relations of collaboration between the members are what will sustain the network and ensure the maintenance and the achievement of the goals (Jones et al., 1997; Dyer \& Singh, 1998; Cullen et al., 2000; Nooteboom, 2004; Balestrin \& Verschoore, 2014). For that reason, it is important for all members involved in the management of a cooperative network to be aware of those relational and collaborative views, in order to be able to, based on those premises, plan and manage.

\subsection{Game Theory, Collaborative Behavior and Innovation Networks}

Game theory studies strategy games and can be applied to various contexts involving a conflict of interests common to different parties. In the field of Management, game theory has been frequently used to study cooperative scenarios. Considering cooperative studies, game theory has contributed to exploring the issues of cooperative strategies (Winckler \& Molinari, 2011), organizational dilemmas (Sharma \& Bhattacharya, 2013), and issues regarding organizational behavior and cooperative strategies for generating innovation (De Melo \& Câmara, 2008; Ozkan-Canbolat \& Beraha, 2016).

Studies having game theory as a theoretical foundation have been carried out in contexts in which there is cooperation between organizations seeking to generate innovation. De Melo and Câmara (2008), for instance, demonstrate a scenario where information technology companies benefit from cooperating in research and investments to create innovation. Ozkan-Canbolat and Beraha (2016), in turn, propose a model based on evolutionary games to examine the behavior of organizations when transferring knowledge in order to generate innovation within the context of the network.

Networks are environments essentially suitable for cooperation (Capaldo, 2007; Grassi, 2008), and usually built to generate innovation (Ebers \& Jarillo, 1998). However, collaboration needs to be encouraged and developed among the members for the network to remain sustainable and productive (Jones et al., 1997; Dyer \& Singh, 1998; Cullen et al., 2000; Nooteboom, 2004; Höher \& Tatsch, 2011; Balestrin \& Verschoore, 2014). Therefore, two aspects of game theory could contribute to the study of inter-organizational cooperation networks: i) enlightening behavioral aspects of the network players by addressing what leads people to cooperate and ii) exploring cooperation dynamics between the players based on different scenarios and strategies.

Thus, it is relevant for participants in a cooperation network designed to generate innovation to understand and apply game theory to different contexts, considering the importance of those games to the collaborative aspects of network management. For that purpose, it is necessary to understand the results of such games and the impact they generate on the subject of study in administrative science. The results of the games are referred to as pay-offs, and the set of benefits reached by a player, according to their different strategies, is called a pay-off matrix. Through the pay-off matrix, it is possible to determine what is the best decision to be made by an organization in a given scenario, allowing for a better judgment of whether it is advantageous for a company to cooperate with others or not. In a network that seeks to generate innovation through collaboration, it is important for the managers to understand the relations to game theory in order to plan and make decisions on cooperative strategies.

There is a theoretical branch referred to as evolutionary game theory, in which players create a certain strategy in order to achieve optimal results considering that there are other players with the same goals and that the winning strategies (best pay-offs) will prevail over the others and be considered evolutionarily stable. In his book The Evolution of Cooperation, Axelrod (1984) offers results of simulations in computer tournaments, which were competing for the rank of best strategy in a repetitive game of the prisoner's dilemma. The simulations, which tested the survival rate of any of these strategies in an evolutional scenario, proved that the strategies with the highest survival rate were those with a cooperative tendency. The context of a cooperative network is similar to the scenario of evolutionary games, since it consists of an environment in which several managers plan their strategies based on the dilemma of cooperating with the others or not, always with the purpose of achieving optimal results. Therefore, the prisoner's dilemma could be used to help network managers and 
companies decide what is the best decision to be made in a variety of contexts within an inter-organizational cooperation network.

Regarding innovation networks, the dilemma of cooperating is even more important, since there are, in such environments, issues such as intellectual property; product development; and technology transfer (Tsai, 2001), which could make the members of the network wary about cooperating. There are some questions specific to the process of generating innovation that may be considered deterrents to collaborative behavior, such as: dividing the profit in the development of a new technology; decisions in sectors such as research and development (Arranz \& Arroyabe, 2008; Funk, 2014); trustworthiness among the members (Zaheer et al., 1998; Cullen et al., 2000; Boaventura et al., 2016); or fear that one member could profit more than another.

On the other hand, innovation networks are formed to encourage the generation of innovation among their agents. Several studies show how cooperation networks are organized to share knowledge and information in order to generate innovation (Ebers \& Jarillo, 1998; Breschi \& Marleba, 2005; Funk, 2014). These studies indicate how collaborative and relational views are important for cooperation networks, specifically those with innovative goals and transference of knowledge. Hence, it is important for innovation network managers to envision those aspects and work to show the members what benefits they will attain by participating in a cooperation network, and also when creating governance models addressing such views and when managing in accordance with those principles.

The literature on governance and network management has addressed a number of aspects referring to governance structure, such as rules, sanctions and formal agreements, and control mechanisms including coordination and leadership, usually separately studying what concerns the relationships between network members. However, what in fact sustains an inter-organizational cooperation network are the relationships between their participants (Jones et al., 1997; Dyer \& Singh, 1998; Cullen et al., 2000; Nooteboom, 2004; Capaldo, 2007; Balestrin \& Verschoore, 2014), which are shaped by individual and collective interests (Provan et al., 2007; Höher \& Tatsch, 2011; Balestrin \& Verschoore, 2014) thereby, company managers are interested in belonging to a network. In other words, individual interests lead a member to participate in a network and collectively pursue common goals, obtaining individual and collective benefits. Granted that, how is it possible for the governance structure of a network and its management to be aware of encouraging cooperation in an inter-organizational network, fostering the maintenance and collective development of the network based on the interests of the participants?

The purpose of this theoretical test is to explore this gap in literature, concerning how to address the subjects of the collaboration and relationship, based on governance and cooperation network management, considering collaborative behavior as the variable that results from the intersection of individual and collective mechanisms offered by governance and management mechanisms (Figure 2).

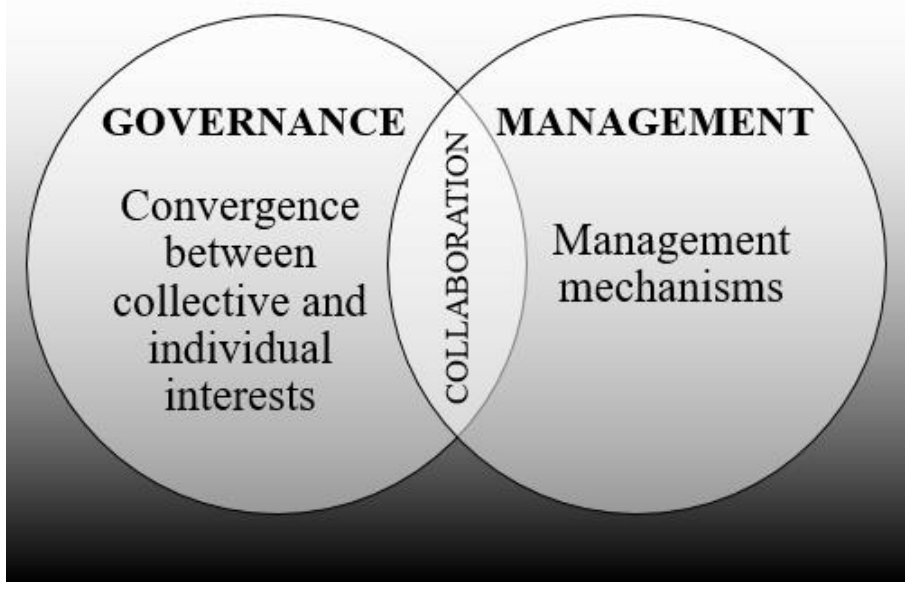

Figure 2. Analytical framework

Source: Developed by the authors

Game theory and prisoner's dilemma (Gibbons, 1992) were used to represent the different scenarios under which network cooperation is intensified in order to establish how collaborative behavior spreads through an organizational network focusing on innovation.

\section{Methodology}

The prisoner's dilemma, developed by Albert W. Tucker in 1950, is a game often used in the application of cooperative 
strategies (Axelrod, 1984; Alencar \& Yamamoto, 2008). It originally simulated a scenario where two prisoners had to decide to expose a third one or not, with an eventual pay-off in the results of their sentences. This game is quite often used in studies where two parties enter in dispute to decide if they should cooperate or not. It could be used to demonstrate scenarios in which cooperation could be assessed as a strategic option.

For our purposes, three other scenarios will be added to the classic result of the prisoner's dilemma, representing different network governance strategies that, by an individual decision, positively affect the collaboration in the network and bring different decision-making contexts to aid the managers of a cooperation network in the dilemma of deciding whether to cooperate. These scenarios intend to show what are the benefits of participating in a cooperation network for the players. Seeing the results of these games might make the managers of innovation networks more likely to cooperate and, more importantly, since they are included in a cooperation network context, more inclined to make decisions that contribute to the relationships among the participants and, therefore, to the all of network's collaborative actions. It is also important for network managers to understand these scenarios in order to adopt management mechanisms based on the premises that encourage collaboration.

These scenarios were based on games presented by Steven Pinker (2011) in his book The better angels of our nature, in which he demonstrated the reasons why violence has declined over the past few centuries of humankind. These reasons were summarized in three scenarios: the Leviathan; Gentle Commerce; and the Expanding Circle. These three games that modify the classic prisoner's dilemma were adapted to conditions that could increase collaboration in an innovation network. Thus, based on Pinker's games (2011), three contexts will be discussed in which the managers can face, inside or outside a scenario of cooperation, other players in an innovation network, which could, for instance, be science and technology institutions represented by their researchers, research groups, technology-based companies and technological innovation centers.

The first scenario concerns a player's decision to participate or not in a cooperation network (classic prisoner's dilemma). The second scenario seeks to alter the initial conditions of the prisoner's dilemma, showing what happens when the players realize that non-collaborative behavior in the network can be penalized with loss of information, knowledge and access to the researches and infrastructure developments of other network agents. The third scenario shows the modification of the classic game by including the players' perception that collaborating in the network offers a gain provided by tit-for-tat relations in the network through the exchange of knowledge. Finally, the fourth scenario includes the perception of social responsibility in the network brought to the agents by the development of the feeling of empathy to the other members of the network.

Therefore, after presenting the scenarios under which collaboration among the players of one innovation network could be encouraged, governance strategies and management mechanisms are proposed for the application in innovation networks, seeking to raise collaboration and consequently align governance and management aspects, leading to the convergence of individual interests into collective goals and interests. The purpose, based on the literature, is to complement the test with signs of its empirical confirmation, helping network managers to build strategies of governance and management mechanisms, which enable the creation of network collaboration scenarios that lead to innovation.

In order to reach the purposes of the research, five managers of technological innovation centers (NITs) were interviewed, belonging to a network of 22 (twenty-two) NITs of public and private research and development institutions, distributed throughout the State of Ceará. In these interviews, the opinions of those managers regarding the scenarios presented and the governance and management mechanisms proposed for each scenario were collected, so that each proposed scenario/mechanism would be relevant for the management of the network to which they belong.

In short, the paper has three methodological steps: the first step proposes three scenarios that alter the classic results of game theory in order to enable players to decide whether to collaborate in a network of innovation; the second step relates the characteristics of the proposed scenarios to the mechanisms of management model and network governance; and the third step supports, through managers participating in an innovation network, the use of these mechanisms as a way to encourage members to collaborate (figure 3 ). 


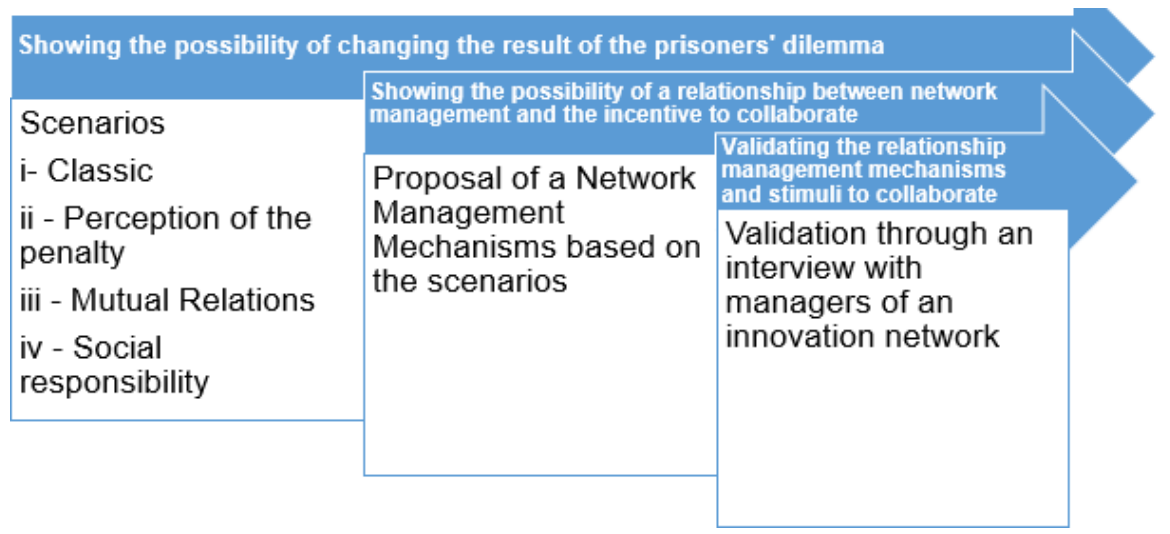

Figure 3. Methodological steps

Source: Developed by the authors

\section{Results}

\subsection{Prisoner's Dilemma and Collaboration in Inter-Organizational Networks}

The diagram of the classic prisoner's dilemma (Table 1), applied to the dilemma of collaborating or not with the other members in an innovation network, shows the result of the game by a dominant strategy, which is the decision by two players or agents of the innovation network not to cooperate. Here the pay-offs represent the perception of gain or loss with these relations in the innovation network, such as access to more information and knowledge and the resources for research, development and innovation (Arranz \& Arroyabe, 2008; Funk, 2014).

Table 1. Pay-off matrix of the prisoner's dilemma to participate in a collaborative network

Source: adapted from Pinker (2011).

\begin{tabular}{l|c|c}
\hline Strategies & To cooperate & Not to cooperate \\
\hline To cooperate & $(5)$ & $\mathbf{( - 1 0 0 )}$ \\
Not to cooperate & $(5)$ & $(10)$ \\
& $(-100)$ & $(-50)$ \\
\end{tabular}

Participating in a cooperative network may bring many benefits for a company, such as sharing information, knowledge and resources among the members (Ebers \& Jarillo, 1998; Verschoore \& Balestrin, 2008; Alves et al., 2011). Therefore, the second scenario addresses a manager's decision to participate or not in a cooperative network. So, as table 2 shows, the classic prisoner's dilemma has its pay-offs modified with a penalty or perception of major loss, for not having enjoyed sometimes better resources and knowhow shared by the network than in the original game when compared to non-cooperative strategies.

Table 2. Pay-off matrix of perceived penalty, through loss of information, knowhow and R\&D infrastructure.

An identifiable loss is made by non-collaboration: one and a half times the gain in form of losses from not cooperating in a network.

\begin{tabular}{l|c|c}
\hline \multicolumn{1}{c|}{ Strategies } & To cooperate & Not to cooperate \\
\hline & $(\mathbf{5})$ & $(-\mathbf{1 0 0})$ \\
To cooperate & $(5)$ & $(10-15=-5)$ \\
\hline Not to cooperate & $(\mathbf{1 0 - 1 5}=\mathbf{- 5 )}$ & $\mathbf{( - 5 0 - 1 5 0 = - 2 0 0 )}$ \\
& $(-100)$ & $(-50-150=-200)$ \\
\hline
\end{tabular}

Source: adapted from Pinker $(\overline{2011)}$

By joining a cooperative environment, an organization has the opportunity to enjoy the aforementioned benefits, as long as the company maintains a good relationship with other companies, building a good relationship, reputation and trust. This is the scenario of the third game, called "mutual networking relationships", which addresses a company's dilemma in maintaining good relations with others to enjoy the benefits of networking (Gulati, 1995; Jones et al., 1997; Cullen, Johnson \& Sakano, 2000). In this case (Table 3), the classic game has its pay-offs altered, the innovation network agents representing this perception, which determined an additional gain of 100 (a substantial sum \} for the strategies when, were moved by a feeling of trust that led the players to mutually decide to cooperate in the network. 
Table 3. Pay-off matrix of mutual relations in innovation networks (Nash equilibrium)

\begin{tabular}{l|c|c}
\hline Strategies & To cooperate & Not to cooperate \\
\hline To cooperate & $(\mathbf{5 + 1 0}=\mathbf{1 5})$ & $\mathbf{( - 1 0 0 )}$ \\
Not to cooperate & $(5+10=15)$ & $(10)$ \\
& $(-10)$ & $\mathbf{( - 5 0 )}$ \\
& $(-100)$ & $(-50)$ \\
\hline
\end{tabular}

Source: adapted from Pinker (2011)

The fourth game deals with the matter of social responsibility. This game involves a scenario where concern with other players in the network is so relevant that a player's pay-offs are absorbed by the other (tit-for-tat), moved by creating empathy between the networking players (Ritter \& Gemünden, 2003; Greer \& Lei, 2012; Uebelherr, Hondula \& Johnston, 2017). In the pay-off matrix (Table 3) one player's result was added to that of the other, inverting the result of the classic game to mutual collaboration.

Table 4. Pay-off matrix for social responsibility in innovation networks.

Empathy towards the results of other members in the network makes a player absorb the pay-off of others (tit-for-tat).

\begin{tabular}{l|c|c}
\hline Strategies & To cooperate & Not to cooperate \\
\hline To cooperate & $\begin{array}{r}(5+5=10) \\
(5+5=10)\end{array}$ & $\begin{array}{r}(-100+10=-90) \\
(10+-100=-90)\end{array}$ \\
\hline Not to cooperate & $\begin{array}{l}(\mathbf{1 0 + - 1 0 0}=\mathbf{- 9 0}) \\
(-100+10=-90)\end{array}$ & $\begin{array}{c}\mathbf{( - 5 0 + - 5 0}=\mathbf{1 0 0}) \\
(-50+-50=100)\end{array}$ \\
\hline
\end{tabular}

Source: adapted from Pinker (2011)

\subsection{Strategies of Governance and Innovation Network Management Mechanisms}

Table 5 is based on the scenarios proposed in item 4.1 and seeks to demonstrate that there may be mechanisms in the literature on network management and governance that are capable of creating conditions for the establishment of the proposed collaborative scenarios, revealing that, theoretically speaking, it is possible influence the collaboration of the actors of an innovation network through the application of the right management tools.

Thereby, table 5 is based on the these scenarios, with the first column representing different scenarios of governance strategies, where innovation network managers need to have good basses to prepare their management mechanisms. These mechanisms, in the second column, are to help the individual interests of the network players to be focused on the collective networking interests and goals, in order to enhance the results of the networking participants' collective actions. These management mechanisms were based on the literature on networking governance and management, mainly using the studies regarding networks in the context of innovative environments.

Table 5. Innovation Network Management Mechanisms

\begin{tabular}{|c|c|c|}
\hline $\begin{array}{c}\text { Governance } \\
\text { strategy scenarios }\end{array}$ & Network management mechanisms & Literature \\
\hline \multirow{3}{*}{$\begin{array}{l}\text { Perception of } \\
\text { punishment by loss } \\
\text { of information, } \\
\text { knowhow and R\&D } \\
\text { infrastructure }\end{array}$} & $\begin{array}{r}\text { To help build R\&D pr } \\
\text { networking a }\end{array}$ & \multirow{3}{*}{$\begin{array}{l}\text { Ebers \& Jarillo, 1998; Dyer \& Nobeoka, 2000; Tsai, } \\
\text { 2001; Nooteboom, 2004; Breschi \& Malerba, 2005; } \\
\text { Capaldo, 2007; Arranz \& Arroyabe, 2008; De Melo } \\
\text { \& Câmara, 2008; Verschoore \& Balestrin, 2008; } \\
\text { Zeng et al., 2010; Alves et al., 2011; Funk, 2014; } \\
\text { Ozkan-Canbolat \& Beraha, } 2016\end{array}$} \\
\hline & $\begin{array}{c}\text { To establish a transparent supply of } \\
\text { shared infrastructures between } \\
\text { networking members }\end{array}$ & \\
\hline & $\begin{array}{c}\text { To disseminate learning gains and } \\
\text { R\&D results that are the result of the } \\
\text { collaborative/ collective action of } \\
\text { networking agents }\end{array}$ & \\
\hline \multirow{3}{*}{$\begin{array}{l}\text { Perception of gains } \\
\text { with mutual } \\
\text { relations innovation } \\
\text { networks }\end{array}$} & $\begin{array}{l}\text { To encourage dive } \\
\text { relations in }\end{array}$ & \multirow{3}{*}{$\begin{array}{l}\text { Gulati, 1995, 1998; Cullen et al., 2000; Provan et } \\
\text { al., 2007; Provan \& Kenis, 2008; Höher \& Tatsch, } \\
\text { 2011; Brand et al., 2014; Verschoore et al., } 2014\end{array}$} \\
\hline & $\begin{array}{l}\text { To share and interact with networking } \\
\text { members based on group affinity }\end{array}$ & \\
\hline & \begin{tabular}{|l|} 
To disseminate the gains in mutual \\
relations between networking players
\end{tabular} & \\
\hline \multirow{2}{*}{$\begin{array}{l}\text { Social } \\
\text { responsibility in } \\
\text { innovation } \\
\text { networks }\end{array}$} & $\begin{array}{c}\text { To visit and present practices and } \\
\text { problems between networking players }\end{array}$ & \multirow{2}{*}{$\begin{array}{l}\text { Jones et al., 1997; Dyer \& Singh, 1998; Grassi, } \\
\text { 2008; Balestrin \& Verschoore, 2014; Balestrin et al., } \\
2014\end{array}$} \\
\hline & $\begin{array}{l}\text { To host events to bring networking } \\
\text { players together }\end{array}$ & \\
\hline
\end{tabular}

Source: prepared by the authors 
Five managers of institutions participating in a collaborative innovation network in the State of Ceará (RedeNit-Ce) were interviewed for an empirical validation of the management tools presented in table 5 , in order to know how those mechanisms can influence the decisions of the actors of an innovation network about mutually collaborating. These interviews were designed to collect the impressions of these managers, all network members, about the importance of network managers' knowhow regarding governance strategies through this theoretical test and its impact on the members' collaborative behavior. A questionnaire was also applied addressing the management mechanisms proposed in this theoretical test. The results of the interviews with the network managers are discussed below.

Regarding the first governance strategy, these managers show a clear concern for network management to raise awareness on the functioning of networking, to enable networking players to perceive how important it is to be included in innovative environments (Tsai, 2001; Breschi \& Malerba, 2005; Funk, 2014) and also awareness of the losses caused by not participating in these innovative and collaborative networking environments. This is expressed in the words of interviewee P1 "It's important to program a workshop on what networking is and what it means. Because many people are not used to thinking about sharing spaces, which is the major benefit of the network, since you have partner institutions and can do research in these spaces (...). It is important to build these people's capacity to learn the advantages of this work (...) so that they are aware of the problems faced when not networking. We must work on raising awareness". Manager P3 also mentions: "By networking you have access to projects and the possibility of doing projects together, which can bring resources and make the project stronger".

Regarding the second governance strategy, the interviewees reported how important network managers are for network players, emphasizing the benefits of networking (Gulati, 1995, 1998; Cullen et al., 2000; Balestrin \& Verschoore, 2014). Interviewee P2 believes that "today, if you don't network or have means of cooperation, partnerships, you are doomed to isolation and will fail to achieve much (...). No institution makes good progress without forming partnerships or networking".

Along this same line, manager P3 argues that, "Without networking you lose a lot of strength when considering contacts; as well as other possible partnerships that could arise from these contacts (...). I think this is the biggest benefit for anyone who networks, that is, the matter of contacts". In turn, participant P4 points out that "Participation in public tenders is more effective when networking. We often announce federal government tenders and from other sources through virtual media. It is, therefore, necessary to make it clear to the members that as a network we are stronger". Lastly, interviewee P5 concludes: "I believe that a visit from some people in the network would be important to be able to disseminate more about the benefits of networking; because, in fact, this culture is relatively unknown (...)".

Considering the third governance strategy, regarding the feeling of empathy among network players, the managers say how important this is for the network's performance (Jones et al., 1997; Dyer \& Singh, 1998; Grassi, 2008). According to manager P2 "We must stress the importance of forming partnerships, emphasizing for members the importance of networking. As soon as we had several collaborative projects and everyone participated, all members of the network benefited. At the same time, when unable to undertake projects, everyone is affected. So everyone is socialized with each other, the network has done this very well (...) through virtual groups and meetings (...). The main issue for this mechanism is the transparency of management (...), and for this the virtual media are important".

Participant P3 adds: "the best way to demonstrate this is in real-time, but also something could be done by informing what has already been a success in the network. To inform less active people how they could benefit, through events, lectures (...). It should also be clarified what must be done, and for this to happen everyone needs to cooperate to achieve this goal". Furthermore, interviewee P5 points out that "In the shared meetings it is important for everyone to give opinions, and also to know what the others are doing".

During the interviews, the questionnaire addressed the importance of management mechanisms for the collaborative behavior of the members. The interviewees were encouraged to rate from 0 to 10 the importance of such mechanisms for the management of a collaborative innovation network. The results are given in table 6 , where it is noticeable how the managers stress the importance of management mechanisms that enable integration and sharing of resources among the members (Dyer \& Singh; 1998; Ebers \& Jarillo, 1998; Höher \& Tatsch, 2011). 
Table 6. Results of the questionnaire used with managers

\begin{tabular}{|c|c|c|c|c|c|c|c|}
\hline \multirow{2}{*}{$\begin{array}{l}\text { Governance } \\
\text { strategy scenarios }\end{array}$} & \multirow{2}{*}{$\begin{array}{l}\text { Network Management } \\
\text { Mechanisms }\end{array}$} & \multicolumn{5}{|c|}{ Interviewees } & \multirow{2}{*}{ Aver. } \\
\hline & & P1 & P2 & P3 & P4 & P5 & \\
\hline \multirow{3}{*}{$\begin{array}{l}\text { Perception of } \\
\text { punishment by } \\
\text { loss of } \\
\text { information, } \\
\text { knowhow and } \\
\text { R\&D } \\
\text { infrastructure }\end{array}$} & $\begin{array}{l}\text { To help build R\&D projects } \\
\text { between networking agents }\end{array}$ & 10 & 9 & 9 & 8 & 10 & 9.2 \\
\hline & $\begin{array}{l}\text { To establish a transparent } \\
\text { supply of shared } \\
\text { infrastructures between } \\
\text { networking members }\end{array}$ & 10 & 8 & 10 & 7 & 10 & 9 \\
\hline & $\begin{array}{l}\text { To disseminate learning gains } \\
\text { and } R \& D \text { results that are result } \\
\text { of collaborative/collective } \\
\text { action of networking agents }\end{array}$ & 10 & 9 & 10 & 9 & 10 & 9.6 \\
\hline \multirow{3}{*}{$\begin{array}{l}\text { Perception of } \\
\text { gains with mutual } \\
\text { relations } \\
\text { innovation } \\
\text { networks }\end{array}$} & $\begin{array}{l}\text { To encourage diversity in } \\
\text { one-to-one relations in the } \\
\text { network }\end{array}$ & 9 & 7 & 9 & 9 & 8 & 8.4 \\
\hline & $\begin{array}{l}\text { To share and interact with } \\
\text { network members based on } \\
\text { group affinity }\end{array}$ & 9 & 8 & 10 & 10 & 10 & 9.4 \\
\hline & $\begin{array}{l}\text { To disseminate the gains in } \\
\text { mutual relations between } \\
\text { network players }\end{array}$ & 10 & 8 & 9 & 9 & 8 & 8.8 \\
\hline \multirow{2}{*}{$\begin{array}{l}\text { Social } \\
\text { responsibility in } \\
\text { innovation } \\
\text { networks }\end{array}$} & $\begin{array}{l}\text { To visit and present practices } \\
\text { and problems between } \\
\text { networking players }\end{array}$ & 10 & 8 & 9 & 8 & 10 & 9 \\
\hline & $\begin{array}{l}\text { To host events to bring } \\
\text { networking members together }\end{array}$ & 10 & 8 & 10 & 9 & 9 & 9.2 \\
\hline
\end{tabular}

Source: prepared by the authors

\section{Conclusions}

The findings of this research may contribute to the improvement of network management and governance models, regarding their social and collaborative aspects, especially in the context of innovation networks, by exposing how the rational decisions of the agents who participate in innovation networks, in light of the prisoners' dilemma, can be used strategically to manage network environments, making them more collaborative.

For that matter, the present paper contributes to the literature by showing, theoretically and empirically, that it is possible to use management and governance mechanisms to enable actors to align their individual interests with the collective purposes of the innovation network of which they participate. All of the management and governance mechanisms proposed were relevant, considering the empirical validation. However, greater attention should be attributed to the following: i) Construction of collaborative projects; ii) Dissemination of collaborative learning gains; and iii) Promotion of interaction among network actors; confirming that all the proposed scenarios should be stimulated together in order to encourage collaboration.

As limitation to the work, it is possible to mention that the empirical validation was based on interviews and questionnaires applied to actors of an innovation network and that the answer may not have reflected what would happen in a real scenario experience of these mechanisms, with isolation of variables and the establishment of a control group. For that purpose we suggest that future researchers should apply more robust empirical validations based, mainly, in experiments.

\section{References}

Alencar, A. I., \& Yamamoto, M. E. (2008). A teoria dos jogos como metodologia de investigação científica para a cooperação na perspectiva da psicologia evolucionista. Psico, 39(4).

Alves, J. N., Balsan, L. A. G., de Moura, G. L., \& Pereira, B. A. D. (2011). As relações de confiança, aprendizagem e conhecimento em uma rede do setor imobiliário. GESTÃO. Org-Revista Eletrônica de Gestão Organizacional-ISSN: 1679-1827, 9(3).

Arranz, N., \& de Arroyabe, J. C. F. (2008). The choice of partners in R\&D cooperation: An empirical analysis of Spanish firms. Technovation, 28(1), 88-100. https://doi.org/10.1016/j.technovation.2007.07.006

Axelrod, R., \& Axelrod, R. M. (1984). The evolution of cooperation (Vol. 5145). Basic Books (AZ). 
Balestrin, A., \& Verschoore, J. (2010). Aprendizagem e inovação no contexto das redes de cooperação entre pequenas e médias empresas. Organizações \& Sociedade, 17(53). https://doi.org/10.1590/S1984-92302010000200005

Balestrin, A., \& Verschoore, J. R. (2014). Réplica-Redes são Redes ou Redes são Organizações?. RAC-Revista de Administração Contemporânea, 18(4). https://doi.org/10.1590/1982-7849rac201410961

Balestrin, A., Verschoore, J. R., \& Perucia, A. (2014). A visão relacional da estratégia: evidências empíricas em redes de cooperação empresarial. Revista Base (Administração e Contabilidade) da UNISINOS, 11(1).

Boaventura, J. M. G., Carnaúba, A. A. C., Todeva, E., Azevedo, A. C., \& Armando, E. (2016). Governance structures and trust: a study of real estate networks. Journal on Chain and Network Science, 16(2), 157-170. https://doi.org/10.3920/JCNS2015.0008

Bortolaso, I. V., Verschoore, J. R., \& do Vale Jr, Á. S. E. (2012). O relacionamento sustenta a cooperação empresarial? Uma análise do relacionamento interno em duas redes horizontais. Análise-Revista de Administração da PUCRS, 23(3), 234-243.

Brand, F. C., Rigoni, E. H., \& Verschoore, J. R. (2014). Governance interorganizacional: um estudo do relacionamento entre agentes econômicos do setor de flores. Desenvolve Revista de Gestão do Unilasalle, 3(1), 99-111.

Breschi, S., \& Malerba, F. (2005). Clusters. Networks and Innovation, Oxford University Press.

Camargo, F., Verschoore, J., \& Padilha, L. (2013). A dinâmica estrutural da gestão interorganizacional: o papel do gestor sob a perspectiva da análise de redes sociais. Revista Base (Administração e Contabilidade) da UNISINOS, 1O(1). https://doi.org/10.4013/base.2013.101.04

Capaldo, A. (2007). Network structure and innovation: The leveraging of a dual network as a distinctive relational capability. Strategic management journal, 28(6), 585-608. https://doi.org/10.1002/smj.621

Cullen, J. B., Johnson, J. L., \& Sakano, T., (2000). Success through commitment and trust: The soft side of strategic alliance management. Journal of World Business, 35(3), 223-240. https://doi.org/10.1016/S1090-9516(00)00036-5

De Melo, R. S., \& Câmara, S. F. (2008). Análise das estratégias de investimentos em P\&D nas empresas de tecnologia da informação e comunicação à luz da teoria dos jogos: O caso do Instituto Titan, em Fortaleza-CE. Revista FFBusiness, 5(5), 37-54.

Dyer, J. H., \& Nobeoka, K. (2000). Creating and managing a high-performance knowledge-sharing network: the Toyota case. Strategic Management 345-367. https://doi.org/10.1002/(SICI)1097-0266(200003)21:3<345::AID-SMJ96>3.0.CO;2-N

Dyer, J. H., \& Singh, H. (1998). The relational view: Cooperative strategy and sources of interorganizational competitive advantage. Academy of Management Review, 23(4), 660-679.

Ebers, M., \& Jarillo, J. C. (1998). The construction forms, and consequences of industry networks, international studies of management \& organization.

Funk, R. J. (2014). Making the most of where you are: Geography, networks, and innovation in organizations. Academy of Management Journal, 57(1), 193-222. https://doi.org/10.5465/amj.2012.0585

Gibbons, R. (1992). A primer in game theory. Harvester Wheatsheaf.

Grassi, R. A. (2008). Cooperação interfirmas: a necessidade da construção de um "paradigma teórico". Ensaios FEE, 28 (1).

Greer, C. R., \& Lei, D. (2012). Collaborative innovation with customers: A review of the literature and suggestions for future research. International Journal of Management Reviews, 14(1), 63-84. https://doi.org/10.1111/j.1468-2370.2011.00310.x

Gulati, R. (1995). Social structure and alliance formation patterns: A longitudinal analysis. Administrative Science Quarterly, 619-652. https://doi.org/10.2307/2393756

Gulati, R. (1998). Alliances and networks. Strategic management journal, 19(4), 293-317. https://doi.org/10.1002/(SICI)1097-0266(199804)19:4<293::AID-SMJ982>3.0.CO;2-M

Höher, R., \& Tatsch, A. L. (2011). Redes de cooperação: o caso da Rede Imobiliárias de Santa Maria, no Rio Grande do Sul. Perspectiva Econômica, 7(1), 15-26. https://doi.org/10.4013/pe.2011.71.02

Jones, C., Hesterly, W. S., \& Borgatti, S. P. (1997). A general theory of network governance: Exchange conditions and social mechanisms. Academy of Management Review, 22(4), 911-945

Nooteboom, B. (2004). Inter-firm collaboration, learning and networks: An integrated approach. Psychology Press. 
Ozkan, C. E., \& Beraha, A. (2016). Evolutionary knowledge games in social networks. Journal of Business Research, 69(5), 1807-1811. https://doi.org/10.1016/j.jbusres.2015.10.060

Pinker, S. (2011). The better angels of our nature: The decline of violence in history and its causes. Penguin UK.

Provan, K. G., \& Kenis, P. (2008). Modes of network governance: Structure, management, and effectiveness. Journal of Public Administration Research and Theory, 18(2), 229-252. https://doi.org/10.1093/jopart/mum015

Provan, K. G., Fish, A., \& Sydow, J. (2007). Interorganizational networks at the network level: A review of the empirical literature on whole networks. Journal of Management, 33(3), 479-516. https://doi.org/10.1177/0149206307302554

Ritter, T., \& Gemünden, H. G. (2003). Network competence: Its impact on innovation success and its antecedents. Journal of Business Research, 56(9), 745-755. https://doi.org/10.1016/S0148-2963(01)00259-4

Roth, A. L., Wegner, D., Junior, J. A. V. A., \& Padula, A. D. (2012). Diferenças e inter-relações dos conceitos de governança e gestão de redes horizontais de empresas: contribuições para o campo de estudos. Revista de Administração, 47(1), 112-123. https://doi.org/10.5700/rausp1029

Sharma, R. S., \& Bhattacharya, S. (2013). Knowledge dilemmas within organizations: Resolutions from game theory. Knowledge-Based Systems, 45, 100-113. https://doi.org/10.1016/j.knosys.2013.02.011

Tsai, W. (2001). Knowledge transfer in intraorganizational networks: Effects of network position and absorptive capacity on business unit innovation and performance. Academy of Management Journal, 44(5), 996-1004. https://doi.org/10.2307/3069443

Uebelherr, J., Hondula, D. M., \& Johnston, E. W. (2017). Using participatory modeling to enable local innovation through complexity governance. In Innovation Networks for Regional Development (pp. 215-236). Springer International Publishing. https://doi.org/10.1007/978-3-319-43940-2_9

Verschoore, J. R., \& Balestrin, A. (2008). Ganhos competitivos das empresas em redes de cooperação. Revista de Administração USP-Eletrônica, l(1), 1-21.

Verschoore, J. R., Balestrin, A., \& Perucia, A. (2014). Small-Firm Networks: hybrid arrangement or organizational form? Organizações \& Sociedade, 21(69), 275-291. https://doi.org/10.1590/S1984-92302014000200005

Winckler, N. C., \& Molinari, G. T. (2011). Competição, colaboração, cooperação e coopetição: revendo os conceitos em estratégias interorganizacionais. Revista ADMpg Gestão Estratégica, 4(1), 1-12.

Zaheer, A., McEvily, B., \& Perrone, V. (1998). Does trust matter? Exploring the effects of interorganizational and interpersonal trust on performance. Organization science, 9(2), 141-159. https://doi.org/10.1287/orsc.9.2.141

Zeng, S. X., Xie, X. M., \& Tam, C. M. (2010). Relationship between cooperation networks and innovation performance of SMEs. Technovation, 30(3), 181-194. https://doi.org/10.1016/j.technovation.2009.08.003

\section{Copyrights}

Copyright for this article is retained by the author(s), with first publication rights granted to the journal.

This is an open-access article distributed under the terms and conditions of the Creative Commons Attribution license which permits unrestricted use, distribution, and reproduction in any medium, provided the original work is properly cited. 